\title{
The conversion of social capital into community development: an intervention in Australia's outback
}

Jenny Onyx, University of Technology, Sydney

Rosemary Leonard, University of Western Sydney

Unlike most social capital research which utilizes cross-sectional design, usually of existing statistics or surveys, the research presented here employed a deliberate intervention to mobilise social capital and study the dynamics of how it influences community development. Given that the aim is to understand the processes by which a social capital intervention plays out in practice, the study is qualitative and interpretive in nature. Following Staber (2007) it is argued that whether or not social capital is able to facilitate development depends on the specific context in which it occurs. The general context for this study was that of small rural towns in outback Australia, which are experiencing decline; where decline is defined as having a substantial reduction (over $30 \%$ in population over the past two decades. This article examines four such towns and the way their particular contexts effect the way they mobilise their social capital to implement an intervention to develop their community.

Following Putnam (1993), social capital is defined as "those features of social organization, such as trust, norms and networks that can improve the efficiency of society by facilitating coordinated actions". Bourdieu (1985:248) defined the concept as "the aggregate of the actual or potential resources which are linked to possession of a durable network of more or less institutionalized relationships of mutual acquaintance or recognition”. For Bourdieu, social capital was a core strategy in preserving and transmitting the cultural capital of the elite. Because all forms of capital can be converted into other (primarily economic) capital, social capital was simply one way of preserving class advantage. However other theorists including Coleman (1988) and Putnam (2000), see social capital as a resource (often the primary resource) that is open to all groups and communities. Schuller (2007) argues that it is not that all capitals are ultimately reducible 
to economic capital, but that they interact in complex ways, and indeed the value of social capital may well depend on its linkage to other capitals, including human capital, financial capital and natural capital. Certainly, social capital is capable of producing a variety of positive outcomes, beyond economic advantage, such as improved health and well-being (Halpern, 2005).

Discussions of social capital distinguish between "bonding” and "bridging” social capital (Woolcock and Narayan, 2000; Putnam, 2000). Bonding social capital appears to be characterised by dense, multi-functional ties and strong but localised trust. It is consistent with Coleman's (1988) research in which the effectiveness of community networks depended on close, intersecting, multi-functional ties. Bridging social capital appears to be characterised by the weak ties described by Grannoveter (1986), as well as a thin, impersonal trust of strangers. Woolcock and Narayan (2000) argue that while localised, bonding social capital operates as effective defensive strategies against poverty, the necessary condition for real economic development entails a shift to other, looser networks. Thus a shift from "getting by" to "getting ahead” entails a shift from bonding to bridging networks. However more recent analyses argue that both bonding and bridging social capital are necessary for sustainable development: bridging to produce new potentialities, but bonding to actualize them (Johannisson and Olaison, 2007; Edwards and Onyx, 2007)

\section{Elements of Bonding social capital:}

Bonding social capital is itself comprised of different but interrelated factors as Onyx and Bullen demonstrated (Onyx and Bullen, 2000). Key factors in bonding social capital include:

Associational density within the community. Indeed this is one of the key indicators of the structural aspect of social capital (Putnam, 1993; Portes, 1998). Community based organisations and associations (including economic, social and environmental enterprises) may facilitate effective responses to crisis or change. A critical mass of cooperating organisations can stimulate creative, resource efficient efforts to achieve common community objectives. While development within and between community- 
based organisations can lead to instrumental outcomes in terms of completed community projects, participation in these organisations can also build individual and community capacity, thereby contributing to the development of the other capacity indicators discussed here.

Participation in community life - this concerns process rather than structure: signs that people are involved in their community. It involves formal membership in community organisations, but also the informal assistance to neighbours and willingness to engage with community action as needed, on an informal basis (Onyx and Bullen, 2000). Shared values - not all values need to be shared but a sense of common purpose is a critical factor in catalysing renewal efforts. The very process of coming together to develop community priorities can provide the impetus for sustained collaborative relationships. The identification of priorities also provides goals which, when achieved, provide a point of reflection for celebration and further learning about how to meet other objectives.

Trust- (Fukuyama, 1995; Misztral 1996) - Involves more than predictability; it entails a level of comfort and positive mutuality in interpersonal relations. Signs of trust in the community include a low crime rate Communities are rarely homogeneous and the acknowledgement of difference and the way conflict is dealt with can foster or destroy trust

Agency - All the evidence points to the significance of "can do" attitude in the community (Onyx and Bullen, 2000, Leonard, 1998; Johannisson and Olaison, 2007; Mansuri and Rao, 2003). It is not enough simply to maintain networks of mutual support. What is also required is that they be mobilized into action, that is, that communities may take the initiative in their own development. Communities that assume control over their own destiny are better able to deal with crises and natural disasters, as well as their own disadvantage. What is important is resilience, a capacity to act, and to learn from this action.

Bridging social capital- The extent to which communities can command their diverse social, professional and information networks to draw upon internal and external expertise, ideas and resources is a crucial feature of regenerative capacity. This includes 
drawing on the expertise of trusted professionals (Giddens, 1990; Leonard and Onyx, 2003). The wider the range of intellectual, technical and material resources available, the greater the options are for negotiating effective and well resourced development strategies. Active engagement of these networks can expedite community solutions by engaging the necessary technical, political and financial support to ensure success. That is bridging social capital is essential to sustainable development.

The role of local government- The World Bank in particular has been instrumental in identifying the crucial role of the state in enabling local development, both in the provision of an enabling culture and in the requisite infrastructure (Woolcock, 1998). In the context of outback Australia, local government often provides the most immediate, relevant, and inclusive reference point for any local development activity, and is therefore likely to be heavily involved in any such process.

In order for social capital to be converted into development, it is likely that other capitals must also be present, probably in an interactive enabling process. Two capitals appear to be particularly important:

The availability of financial capital- Financial capital may not be readily available at first, but one of the tasks of any development project will entail the accumulation of some financial capital. Social capital may be used to achieve this.

The appropriate use of human capital- Here we refer to the sum total of the individual knowledge, skills and physical capacity of people in the community to carry out the necessary actions (Schuller, 2007). In the context of the Outback towns project, local knowledge is important, but so too are the knowledge and skills required of project management.

\section{The impact of social capital on development}

There is increasing evidence that social capital has a major positive effect on economic development within a particular region (eg Putnam, 1993; Knack and Keefer, 1997; Woolcock, 2001 ; Whiteley, 2000; Beugelskijk and Smulders, 2005). However, there is considerable debate over what aspects of social capital are important, whether the effect is necessarily positive, and by what processes social capital may be converted to economic growth. Knack and Keefer (1997) found no evidence of a relationship between 
voluntary activity and economic performance in a cross national sample, but they did identify a relationship between trust and economic performance. Whitely (2000) also found a relationship between trust and economic growth in a larger cross national sample, one that was at least as strong as that between human capital and growth. Beugelsdijk and Smulders (200 ) measured bonding (friends and family) and bridging social capital (density of associational activity) based on the European social values survey and related these measures to economic growth in 54 European regions. They found that bridging social capital was related to economic growth, while bonding was not. However the effect was mediated by a culture of materialism such that post materialist values was positively associated with bridging, while materialistic attitudes and strong bonding reduced regional output growth. These macro-economic analyses are largely supported by Terluin ( 2003) using a pattern matching method of 18 case studies of rural regions in the European Union. High performing regions (high employment growth) demonstrated considerably higher levels of social capital than poor performing regions, with strong internal and external networks. This study is one of the few which is able to give some indication of the processes involved in successful development. The author states:

...the overall findings suggests that actors are the essential and decisive factor in rural development....leading case study regions tend to be characterized by a development process, which is organized and experienced in a democratic, bottom-up process, involving a wide range of local actors....(Terluin, 2003, p339) Much of the developmental literature, particularly that emerging from the World Bank social capital initiative, focuses on social development and the development of the infrastructure required for broader development, such as health, literacy and appropriate use of natural resources. Here again, the evidence suggests that social capital is important, though again with some debate as to whether it is bonding or bridging that counts, or indeed some other variable such as the "capture” by local elites, availability of funding or external policy controls (Mansuri and Rao, 2003; Woolcock, 2001; Halpern, 2005) 


\section{The Context}

As Staber ( 2007 ) argues, how social capital operates depends on the particular context where context is defined as "not merely a general environment that enables or constrains action but a nested setting of structures and processes through which individuals perceive interpret and motivate their actions, and in turn shape context” (Staber, 2007, P 506). Thus while several towns may share a similar general context, each will also be unique in some respects.

There has been extensive documentation of the plight of rural population decline across much of the developed world (Onyx and Leonard, 2000). This decline has been articulated for Australia by Forth (2001) most clearly, as inevitable given the economic, historical and ecological conditions that apply. Overall there has been a redistribution of wealth over the past two decades, with net reduction in wealth of most rural areas. The majority of small towns experiencing population decline are located in rural regions that remain dependent on resource industries, particularly those with high dependence on a single resource industry. With the increased emphasis on global economic "free” markets and economic rationalist policies, there has been a compulsion to increase competitive productivity with the help of reduced labour, more effective capital infrastructure, and the closure of unprofitable services and industries. The effect of this has been reduced government and private services in small rural towns, and the loss of employment opportunities (Forth, 2001). This then constitutes the common context in which this study is situated.

Within that context we explore the dynamics of community development from the perspective of social capital. We examine four outback Australian towns which had volunteered to engage in an intervention to develop a community project that would benefit the town. Within the common context, we examine the specific nested setting of structures and processes which operate uniquely in each town. How was social capital used in each town? What other factors facilitated or impeded its use, and with what kind of outcome? While social capital may be essential for communities, in particular for small rural towns, we know little of how this works. Nor can we assume that high levels 
of social capital will necessarily lead to good developmental outcomes. We explore some of the complexities of social capital in practical contexts (Staber, 2007).

\section{Methodology}

The research involved a two year intervention study of four small outback towns. In each case the research team was invited to explore the possibilities of developing a community project to involve travelling 'grey nomads' who visited the town, as volunteers. We explore the levels of social capital that exist at the outset of the project. We then followed the experience within each town over a one year period. Of particular interest was the way in which social capital intersects with other capitals, particularly with financial and human capital, and the identification of other, context specific factors that may impede or facilitate the mobilization of social capital.

Following Staber (2007, P513) we examine the context of each community project by adopting (1) a thick description of the research setting; (2) a context-sensitive sampling plan; (3) a focus on processes and events; (4) attention to co-evolutionary processes at multiple levels; and (5) attention to the social mechanisms that link actions at multiple levels.

The four towns reported here are Winton and Barcaldine in central-western Queensland, Kimba on the Eyre Peninsula in South Australia and Bingara on the New England Tableland of New South Wales. They are all small towns with populations ranging from 700-1300, located on or near popular tourist routes and one to two hundred kilometres from a major rural centre. In each case the population has declined markedly in the last 20 years but has now virtually stabilised. The towns are heavily reliant on the primary industries of cattle and grain crops and, at the time of study, were facing difficulties from drought and downturns in world commodity prices.

Clearly the four towns have much in common and, as such, presented a useful starting point for examining the effects of an intervention. (Two other towns were very different in size or economic base and therefore their context disallowed meaningful comparison 
so they are not included in this analysis.) One important difference among the four towns, however, was that two (Winton and Barcaldine) have already taken steps to develop a tourist industry, while the other two towns had not done so. In particular, the phenomenon of "grey nomads" is bringing thousands of visitors each year to many outback towns. Grey nomads are defined as people aged over 50 years, who adopt an extended period of travel independently within their own country. Many grey nomads spend considerable time exploring the inland of Australia and visit many outback towns. The evidence suggests that Grey Nomads make a substantial economic contribution to rural communities. In a recent study, the authors found that the Grey Nomads had a wide range of skilled trades that could be of use to people in isolated rural communities on a volunteer basis and they had a strong interest in getting to know the local people. There appeared to be an untapped potential for the development of mutually beneficial relationships between Grey Nomads and isolated rural communities through voluntary programs (Onyx \& Leonard, 2007; Leonard, Onyx \& Maher, 2007). Therefore, the intervention offered by the researchers in partnership with Volunteering Australia was to support the town to develop a grey nomad volunteer program.

A focus on processes and events. An intervention study with ongoing evaluation has the advantage of illuminating the processes and events as they unfold. The procedure was similar in each instance:

The research team was invited by the local government of each town, with support from key community groups and local business. The research team spent four days interviewing up to 20 key informants from as diverse a range as possible, and using a snowball sampling approach. In each town key informants included:

- Elected representatives in local government including the Mayor or Deputy Mayor

- CEO of local government and other paid workers

- Local business owners

- Presidents or office bearers from a range of community organisations

- Coordinators of the Visitor Information Centre and other tourist facilities

- Social service providers including school principals 
- Coordinators of Indigenous groups in Winton and Barcaldine Each informant was asked about their own role in the town, and the nature of key organizations and any connections between them. They were also asked to identify what they considered to be the key strengths of the town, and the key issues or problems faced. Finally they were asked to consider what kind of community wide project, involving grey nomads, would be useful for the town as a whole. Interviews were taped and transcribed. These interviews were supplemented by observational field notes and other secondary data available from the Local Government or national data sources.

From the information collected, the team prepared a simple SWOT analysis (identifying strengths, weaknesses, opportunities and threats) for the town in relation to grey nomads and potential volunteer projects. This was presented to a public meeting of the town, attended by about 30 people, together with a range of proposed projects which the public meeting then discussed and voted on. A Grey Nomads Action Group was then formed of volunteers attending the public meeting (including at least one member of Council). That is, in each town a proposal was accepted by the town to develop a project that would benefit the community as a whole and that would require the co-ordination of visiting grey nomads as volunteers. Contact was maintained, by phone and email, with each town over a one year period, so that events and processes could be documented. Each town was revisited after approximately one year, to identify if and how the town was able to mobilize its social capital to generate the project. This involved another round of site visits and interviews, approximately ten per town.

The information obtained related to actions at multiple levels. Respondents were encouraged to give their accounts in whatever terms they thought relevant, whether that be dynamics within the town, regional or national changes or international forces such as world commodity prices. In particular, participants were asked about aspects of social capital, both bonding and bridging; economic, human and natural capitals and the role of government, local, state and federal. This allowed the researchers to observe at close hand, the key elements of social capital, some of the relationships between social capital 
and the other capitals, and other factors as they facilitated or impeded development in the context of the four towns.

\section{Results}

All four towns are pleasant and well kept without vandalism, empty premises or other signs of neglect and decay. Each has its own elected shire council to manage local government in the area. Employment levels are high, partly because young people tend to move to the city for greater educational and career opportunities. Like most small rural communities there was a general shortage of skilled trades and medical services, but these towns were managing. The towns are marked by a strong predominance of Anglo appearance and culture.

Interviews confirmed the initial impression of high bonding social capital. People wave and greet each other and strangers. There is a strong sense of friendliness and a willingness to work together and help those in need. There are high levels of participation. As one resident of Winton said, "People care about the town and want to be part of it. There are people who give a damn.” The almost unanimous view of interviewees in each town was that the greatest strength of the town was its people. The towns had high levels of associational density; each town having a wide range of sports clubs, historical, cultural and community activities all run by volunteers. However in each town there was a much smaller core group of community leaders who were on the committees of these organizations, with considerable overlap of membership across associations. These active volunteers are largely older, and overcommitted, with fewer young people taking up management positions on committees. Although there were a range of different networks and sometimes individual conflicts none of the towns had major divisions. There were conspicuously high levels of trust within the towns with virtually no crime; people leave their doors unlocked, including keys in the parked car on the main street. Contrary to the reputation of country towns, there was evidence of considerable social entrepreneurship “Things don’t just happen. People make them happen” (Barcaldine resident). 


\section{Case study 1: Barcaldine}

Barcaldine was founded on the wool industry and depends on bores to the Great Artesian Basin for all water. It has a rich history stemming from the shearers strike in the $1890 \mathrm{~s}$ and the subsequent birth of the Labour party, and has a major Australian Workers Heritage Centre. The local economy and population declined with the down-turn in the wool industry. The major industries now are: cattle grazing, government services, tourism, retail and building/ construction. The visitors centre estimates that there are approximately 15,000 visitors a year, of which 70\% are Grey Nomads.

There are a range of active clubs and associations in the town covering sport, welfare, art and heritage. The old theatre is still standing and showing films, run by a volunteer group associated with the arts council. There is also an acceptance of outsiders that doesn't always happen in small towns. There are several Aboriginal families who are well integrated into the community; however the topic of Aboriginal history is generally avoided. It is a town of considerable energy, and initiative.

The only organisation that works across the groups of the town is the Shire Council. The Council has adopted a proactive stance to local economic development. A recent survey by the Barcaldine Business Retention and Expansion taskforce identified a very positive and optimistic attitude of local businesses. Tourism was identified as a major and growing industry with a significant proportion (up to 50\%) of business sales in various sectors going to visitors (Barcaldine Shire Council, 2004). There are more (small) businesses now than ever before, with few vacant premises. The town regularly hosts large groups of external visitors, including for instance very large motor-home rallies which double the town's population for a few days. A retired couple who are returnees to the town are active in the organisation of rallies. Community groups cooperate to fundraise by sharing the catering. The town has also tried to attract Grey Nomads by offering camping space at the showground for a minimal cost, as well as free camping at the Weir, a picnic spot some $20 \mathrm{~K}$ outside town. There is good internet access although older citizens are reluctant to use it. 
Response to the Grey Nomads as Volunteers project The public meeting identified several potential projects, all of which built on existing proposals, but none of which emerged as a clear favourite. The potential projects included the development of bird watching reserve which was part of the local wetlands project. A schools career day project would involve visiting grey nomads to talk about their own career/ occupation/ trade. A suggestion from the grey nomads out at the Weir was to provide a list of maintenance and beautification jobs that Council would like done at the Weir. The Heritage Centre offered the opportunity for volunteers to be involved in tours, promotion, or expansion of displays.

At the time of the follow-up visit year later, at first it appeared that little was happening with the project, as the local chemist, a newcomer to town, who was chair of the committee was leaving again for personal reasons. However, on further enquiry, some eight separate projects were progressing, involving grey nomad volunteers, including all the ideas originally nominated. However no single informant knew about all of them. The problem appeared to be that the committee was preoccupied with issues of publicity, and debating which projects were to be followed. Little attention was given to the necessary infrastructure to enable the project to continue on an ongoing way. There was no central register established, nor any central point of contact for Grey Nomad to go to. There was no one to coordinate the Grey Nomad or their projects, and no agreed policy or procedure to manage the Grey Nomads. However one member of the committee, with Council support, made a successful application for State Government funding for a coordinator for a year. Since that time increasing numbers of community organisations are benefiting from grey nomad volunteers. The only concern is whether the program can continue if funding for the coordinator ceases.

\section{Case study two: Winton}

Early settlers found rich grazing country with water available from the Great Artesian Basin. There was conflict with the resident Aboriginal population, and at least one massacre is recorded. Today there is only one remaining Indigenous family from that time; the bulk of the population is Anglo. In the last 30 years, as the market for wool declined, many properties shifted from sheep to cattle, which are less labour intensive. 
There is also opal mining in the region, and a gypsum quarry. Many young people and skilled workers leave to work for the large mines located some $300 \mathrm{~km}$ away. Tourism has become a major secondary industry mainly associated with the iconic song "Waltzing Matilda," based on an incident near Winton, and the discovery of the largest collection of dinosaur bones in Australia.

Winton has four distinct networks. One network revolves around those involved in the Australian Dinosaur project, including several property owners who have opened their property for scientific digs, citizens who have developed a local museum of dinosaur bones, as well as a commercially viable tourist site of a dinosaur stampede. Over the years this project has received considerable national media attention and state and federal funding. While some informants believe that everyone should be involved in the dinosaur project, others in the town are fairly dismissive of the "bone people". Another network lead by a local woman and the Deputy Mayor surrounds the Outback Festival which celebrates country life. It is run every two years, involving local business and community volunteers and attracts some 3,000 visitors and is largely self-funded. A third network provides sporting activities for young people. A problem with alcohol and young people has been addressed by a Council employed youth worker through a youth action program and school students are now included in Council meetings. The fourth network surrounds the WHAT committee, the Winton Health Action Team, which is open to all residents, has some State government and Shire Council funding, and is concerned with supporting the general health and social wellbeing of the residents, including a very active "Sixties and Better" organisation for older residents. The Shire Council was the only organisation that works across the four networks; however it was not proactive and saw its role as responding to issues raised by the community.

There is no shortage of initiative and entrepreneurship at the individual level. As one key informant noted, "the people of Winton are very independent and get up and do things, don't expect hand-outs and have terrific character”. Both the dinosaur project and the Outback Festival are examples of initiatives driven by a small group of dedicated people, and a well respected leader. It was noticeable that the leaders were not professionals or people elected or employed in positions of authority. 
Bridging social capital was evident at numerous points. All informants and their organizations had some effective bridging links to other towns in the region, to State and Federal government instrumentalities, to broader church and institutional centres, and to businesses outside the town. For example the Outback Festival is largely funded by business sponsorship, mostly from outside the town. Also advertising at the motor-home rally at Barcaldine brought hundreds to Winton for post-rally events. Nevertheless there is an independence of spirit which means that the high level of trust within a network does not necessarily extend to those outside the town or to government.

Response to the Grey Nomads as Volunteers project. The public meeting nominated three projects, all of which were already being discussed or underway: The dinosaur bones, the development of a machinery museum, and the development of Long Waterhole, a passive recreation area near town which could be developed by and for grey nomads but also for local residents. A committee was formed under the aegis of the WHAT group and met monthly for some months. When the researchers returned, a year later, the committee had recorded no achievement, and was attempting to dissolve. It appears that no-one had been prepared to take up a leadership role within this committee. There had been a number of approaches by visiting grey nomads, but there was no point of contact and information was not passed on to any other person. The visitor information centre did not cooperate, perhaps because the manager also owned the Waltzing Matilda museum and did not want people to stay around the town as they would only visit the museum once. The long waterhole project was now dismissed by Council as lacking a clear business plan, even though the CEO had previously expressed considerable enthusiasm for the project. It appears that several neighbouring grazing properties were using the waterhole as a commons for their stock.

After further inquiry it was found that grey nomads volunteers had had a vital role in building the machinery museum which was opened in conjunction with the Outback Festival. Council had supported the development of the museum with the provision of equipment and land. Leadership for this came from the two people who led the Outback Festival committee. Although one was on the grey nomads committee, their achievement had not been formally identified by the committee. Similarly, the dinosaur project was 
well under way, and had a small group of visiting volunteers, but again, without any recognition or engagement of the grey nomads committee. After the researcher's visit and recognition of grey nomads' contribution, the committee regained its energy with the promise of more effective leadership. However no further progress has been reported.

\section{Case Study 3: Kimba}

Kimba has a very narrow economic base, being almost entirely dependent on a single, agricultural economy from grain crops. However the recent planning of a mine in the region may reverse this trend. At the time of the initial visit, the area was in its fourth year of drought but there was little attention paid to grey nomads or the possibilities of generating tourism as a secondary industry. The caravan park was ill-kept and effected by traffic noise thus discouraging a long stay. The Big Galah on the highway is the one, rather run-down, tourist outlet and the owners do not contribute to the life of the town. The town has considerable natural capital as the gateway to the beautiful Gawler Ranges National Park. Because Kimba has no natural water source it did not have a resident Aboriginal community.

There are many small groups all "doing their own thing” with little attempt to network with others. Particularly relevant for grey nomads are the active Historical Society and the Living Museum with their field days with demonstrations of the old farm machinery, blacksmithing and the one teacher school in action. Every year school children in year nine contribute to the exhibits and add a life story of an elder of Kimba to the collection. Residents are resilient and self reliant and creative in finding solutions to local problems. They are prepared to take risks when necessary. This makes for a very vibrant community with plenty of action.

There are, however, three organisations that have broad community involvement. Kimba Shire Council has an avowed philosophy of supporting and assisting the initiatives of local community groups, and where possible integrating and co-ordinating these with other initiatives and with the wider Community Vision. One example of this was the 
buyout of the old hotel, transforming it into the Community Hotel with a range of modern and attractive facilities in the centre of town. This not-for-profit hotel provides a central and attractive hub for services, including a range of accessible and attractive meeting places, in what would otherwise be a dead centre. It provides employment and training opportunities for local young people and makes substantial donations to community groups in town and may eventually provide an additional source of income for the town. It is run by a committee chaired by a local accountant. It appeared that the town had a number of other professionals who were not involved in community leadership. The third community wide group is the very active Community Development Group which is auspiced by Council and lead by a local woman farmer with strong community networks. She has a record of successful projects for her community and was recently given the South Australian, Rural Woman of the Year Award.

There is relatively little bridging to outside networks, and considerable resistance to change. A few groups work cooperatively within the Eyre Peninsula, for example holding the annual Kimba races in Port Lincoln. Council and the Community Hotel use external consultants to bring in specialist knowledge and skills as required. But most of the life of the community is focused inward, and self reliance is the catch-cry. Although some people in Kimba had heard that a motor-home rally was planned for Whyalla, the nearest large centre, they were not gearing up to take advantage of the influx of visitors.

Response to the Grey Nomads as Volunteers project The project itself generated considerable interest and the public meeting attracted a relatively large crowd. Two projects in particular were identified: the development of the show ground to accommodate Grey Nomads and other caravaners, and a grey nomad volunteer program for the living museum. An active committee was formed, independent of but linked to the Community Development Group and led by the same woman. The committee recognized that a first step in their task was to establish a viable visitors' centre to assist grey nomads and other tourists. This was done in the following six months, with Council support, and drawing on 68 local volunteers, who were trained for the job. By the time of the followup visit a year later, the visitors' centre was running, suitable space for grey nomads had 
been identified, the new owner of the existing caravan park was keen to develop good relations, and detailed negotiations had begun for six local volunteer projects. An administrative system had been established to manage the grey nomad volunteer project, and the committee was about to initiate a recruitment program for grey nomad volunteers. Since that time a small number of volunteers have stayed in Kimba.

\section{Case Study 4: Bingara}

Bingara is an attractive place for urban retirees looking for a change of lifestyle in a more relaxed, rural setting. The major industry is beef, and some sheep but it is struggling in an ongoing drought. The timber mill was closed during the last 10 years and the soil is not good enough for cash crops. The area has a rich history of mining mainly gold and precious gems, but is infamous as the site of the Myall Creek Aboriginal massacre in the early settlement time. There are now no Aboriginal families in town. The town itself has plenty of water from the dam built to supply cotton farmers in the next shire. There are plenty of beautiful fishing and camping places along the river and the Council run caravan park in picturesque and inexpensive. The restored Roxy theatre is a gem of Arte Deco design and is becoming a magnet for cultural and social activities and visitors sometimes by the busload. Tourism has been a small element in the economy and is not as well developed as it might be.

This small community has a large number of community events, about one per month. Although many centre on the Roxy, the orange picking festival with 20 floats is a highlight. The children of the town care for the trees and guard the oranges so none are picked until the festival. There are no major divisions and people work together when needed, for example supporting four families whose children had cancer.

Groups that work broadly across the associations of the town are the Shire Council, Gwydir Learning Region and Vision 20/20. Bingara Shire Council has an avowed philosophy of supporting and assisting the initiatives of local community groups, and where possible integrating and coordinating these with other initiatives and with the wider community vision. Often they assist with obtaining resources from government 
departments. The Gwydir Learning Region had just won the State and was runner up in the National awards as a Learning Region, an initiative of the headmaster of the local high school. A unique feature is the tailored programs for high school students focusing on employment often through traineeships so that more young adults can stay in the area. All young people in Bingara are in employment or education as the programs are tailored to the stated needs of the individual students. Expertise is brought into the town or, where this is not possible, students are billeted in larger centres. The learning region is a "grow your own" response to the rural skill shortage with all local businesses and trades people being encouraged to take on trainees and apprentices. Adult education is also important. A good example was the TAFE program introduced to address the shortage of aged care workers which gave employment to a number of people in Bingara and more remote towns. The Vision 20/20 development group, a Council sponsored group involving local business and community groups, is planning many more programs in line with the Vision 20/20 community plan. The leader was a relative newcomer who owned a large local retail outlet. Although respected for his energy and commitment to the town, he was not always able to maintain the co-operation of other residents.

Response to the Grey Nomads as Volunteers project. At the public meeting, several projects were identified which were associated with Vision 20/20, for example the development of a riverside recreation area, including walks, landscaping, a bird hide, and Bingara Farm Gardens Project, which is a large scale venture involving market gardens for commercial and educational purpose. The most popular was not on the Vision 20/20 list. It involved the development of the old Upper Bingara old goldmining site with free camping near the waterhole, restoration of old cemeteries with European and Chinese graveyards, restoration of old one room school building and the historic inn, together with historical research. The town successfully negotiated to have a motor-home rally the following year and planned to encourage the visitors to volunteer. By the time of the follow-up visit a year later, planning for all these events was well underway, except that the Upper Bingara site was put on hold pending new legal leasing negotiations. However thee projects were organised by Council together with Vision 20/20 and there had not yet been any attempt to develop an administrative system to manage the grey nomads once 
the projects were underway. This is unlikely to happen until a designated town committee is appointed, one able, unlike Vision 20/20, to work collectively across the existing community groups. Since then the town has been preoccupied with staging the rally.

\section{Discussion}

In each town there was evidence of the use of all forms of capital (natural, financial, human and social capitals) as well as the specific interaction between different capitals. Natural capital was important, not just as a resource to be exploited for farming, but also as a focus of social capital determination to preserve local natural heritage, eg The Lagoon in Barcaldine, and river-scape in Bingara. The link between financial capital and social capital is also clear. The most obvious connections occur when funding is required to carry out a project, or when lack of finance prevents the initiation or completion of a project. There was little evidence of this. In most cases, the action of organizing was done using social capital; people simply agreed to work together to achieve an outcome. When funding was required it was mainly accessed through Council. That is, it was not the case that economic capital drove the development, but that social capital was used, where necessary, to obtain economic capital. The most obvious case of this, one making use of bridging social capital, was the successful application for State funding from Barcaldine grey nomads committee, through Council, to support an ongoing coordinator. Similarly, the Winton Outback Festival committee used its social capital to mobilize very large sponsorship capital from outside the town.

Each town also had some stocks of human capital, but these stocks were often stretched to the limit. Most small towns do have people with professional skills who are active in the community, but these are few in number and under enormous demand for their volunteer commitment as well as their professional knowledge. The most valuable human asset, in terms of community capacity comes from those local people who have studied and worked away from home for some years, but then chosen to return to work in their home community. Also valuable are those professional early retirees seeking a change in lifestyle. Both groups have a long term commitment to the local community. Other professionals, while welcome, tend to be on contract or short term secondment for a few years at most. There appears to be increased use of consultants to fill immediate and short 
term needs. However Bingara, and to a lesser extent Kimba, have developed training schemes for young people. The various projects proposed by the local grey nomad committees mainly depended on those local technical skills already available, if not within the committee, then through Council. Social capital was thus used to mobilize existing human capital, but not to create new capital.

All four case studies clearly demonstrated strong stocks of social capital, particularly of bonding social capital. In each case there was high associational density, as indicated by the relatively large number of active community organisations, covering a range of sporting, cultural and social purposes. There was evidence of very high levels of formal and informal volunteering, and broad community participation. There was in each case, little crime or vandalism, and no major social conflict evident.

Contrary to the popular conception of country towns, there was strong evidence for local agency and entrepreneurship. Each community had taken important initiatives in recent years to establish new projects that would support the community both economically and socially. In each case these were supported by the Shire Council, with provision of land, facilities, or financial support to establish the project. However in each case identified, the projects were carried out with the larger cooperation of business and community groups.

External Bridging and Linking networks were evident in each town, but these were not as strong or effective as the internal bonding networks. Initiatives had been taken in the past, and each of these involved some bridging or linking networks to organisations outside the town. These are evidenced for example in both the dinosaur project and the Outback Festival in Winton, by the Heritage Museum in Barcaldine, and by the Learning Region awards in Bingara. In each case these bridges were supported, and in some cases initiated by the Shire Council. However, there was also a strong ethic of self sufficiency within most towns, and a preference to use local resources. This was particularly strong in Kimba, but evident in other towns as well. 
Although times were tough for those in extended drought many rural people have a longterm view of cycles of prosperity and hardship and so there was no sense of crisis or the urgent need for action; just the hope that next season would be better. Winton and Barcaldine were protected from drought by the Great Artesian Basin and they felt that the rural decline had levelled off thus they also felt no urgent need for action. There was thus a paradox evident in each town. This paradox was marked by high levels of initiative and agency by particular groups and individuals, often appearing to operate as a kind of island of social entrepreneurship within a larger, still pond of inaction. Those who were active were very active, drawing on resources from within the community, supported by many volunteers, but also drawing on resources from outside the community. Their projects were explicitly seen to benefit the whole community, and were supported as such. But their sphere of operation was limited to the one project of interest. There could thus be several such centres of entrepreneurial activity within the town, with almost no overlap between them. Again, Winton demonstrates the best example of this. But in the other towns as well, there appeared to be a kind of pact of "live and let live", avoiding the potential conflict of competing interests in a small town.

As a result, there appeared to be a lack of formal co-ordination or communication processes and structures. Indeed it was often assumed that "everyone knew everything that was going on” and so there was no need to formalize communication. Many initiatives were restricted to a very small local group without the engagement or knowledge of other relevant groups within the community. There thus appeared to be very high levels of bonding social capital within specific networks, but little capacity to mobilize the social capital between existing structures within the community. Local Government through the Shire Council could play a key role in each town. They had the capacity to link local interest groups, for example engaging them on local projects or Council committees, provide considerable in-kind resources (land, equipment, professional skills) and provide some funding to community groups. Each CEO made it clear that Council could only respond to initiatives from the community; it could not impose initiatives if the community was unwilling to embrace them. However there were considerable differences in how actively the four Councils responded. Bingara was the 
most pro-active, encouraging community planning through Vision 20/20 and then making it happen. Kimba supported the community development group to develop new projects. Barcaldine was also pro-active in their response helping access funding for a coordinator. Winton, in contrast, appeared to be responding to negative pressure from the graziers who used the waterhole and the manager of the Waltzing Matilda Centre.

In theoretical terms, we are here confronted by a problematic interaction between social capital and human capital. While (Schuller, 2007) emphasizes that the two are often linked, it is usually assumed that social capital is a catalyst for disseminating human capital, that is the human capital may be "dead capital” if not put into circulation with the aid of social capital networks (Adam and Roncevic, 2003). However, the direction of influence goes both ways. In the case of these outback towns, there is the problem of accessing the necessary skills and knowledge to be able to mobilise the social capital. What appears to be missing in some cases is the necessary management skills required to organise a project of this sort. This suggests the crucial role of leadership. Leadership which mobilises social capital across a community must strengthen and increase the horizontal ties that create the social capital. Therefore it cannot redirect horizontal relationships into vertical leader-follower relationships The kind of leadership required here is quite different from the classical bureaucratic management model, and quite different from the normal employer relationship (Avery, 2004). What is required is organic leadership, with a community leader who has the capacity to negotiate across equals, to support and facilitate, to create formal communication channels and processes, to identify problems and needs, to work inclusively to solve these. It involves a future vision which is larger than any single group within the community. The outstanding example of this occurs in Kimba which is driven by a local woman farmer but who works inclusively with others across the community. There is a high level of trust within the community development committee which is managing the project, and from other groups. Although Bingara had a community development organisation through Vision 20/20, and the leader has a clear vision, he used a top down style which alienated many community groups. By contrast, in Winton there was little evidence of trust, or collaboration between committee members across networks, or of any sort of active 
leadership that might have brought these disparate groups together. In Barcaldine the professional coordinator is working well across the community but is dependent on insecure funding.

This is not to say that small towns lack leadership. But the existing leadership patterns may not be adequate to cope with a new, community wide project such as this, unless there is an existing group with a broad community development role. Councils may indeed sponsor it, but generally they are unwilling to be interventionist, in the absence of a strong grass roots push. Community groups are generally small, protective of their own interests, prepared to live and let live, but lack a broad community wide remit. What is required here is a form of social entrepreneurship (Mair and Marti, 2006), such as was signalled by Johannisson and Olaison (2007) in their discussion of 'enactive entrepreneurship' associated with social creativity. The characteristics required for enactive entrepreneurship in an emergency, may also be useful or necessary in the case of an emergent community wide project such as the grey nomad project. However where there is no sense of emergency or even of growing crisis, then the kind of rupture of everyday life necessary for the mobilization of this kind of entrepreneurship may not happen. Nonetheless the role of social capital in this case may be the facilitating of "social bricolage” to generate effective collective action (Johannisson and Olaison, 2007, p72).

In conclusion, the case studies demonstrated distinct responses to the intervention depending on their particular contexts. Rural communities have the capacity to mobilize for action, and they may have the willingness to do so. But whether this capacity is actualized may well depend on the presence of other mobilizing factors. In particular there needs to be a structure which can take the initiative and work across the community engaging a range of organisations. Secondly the structure needs to be supported by, but not controlled by, local government. Thirdly it needs the kind of social entrepreneurship that can sustain a community wide vision and bring the diverse groups within the community together. 


\section{References}

Adam, F. and Roncevic, B. (2003) Social capital: recent debates and research trends. Social Science Information. 42, 2, 155-183.

Avery, G. 2004 Understanding Leadership London: Sage .

Beugelsdijk, S., and Smulders, S. Bridging and Bonding social capital: Which type is good for economic growth?

Coleman (1988) “Social Capital in the Creation of Human Capital,” American Journal of Sociology, 94, 95-120.

Forth, G. (2001) Following the yellow brick road and the future of Australia's declining country towns. In M. Rogers and Y. Colllins (Eds) The Future of Australia's country Towns. Bendigo, La Trobe University Press.

Fukuyama, F (1995) Trust: The Social Virtues and the Creation of Prosperity. Free Press, New York.

Giddens, A. (1990) The Consequences of Modernity. Cambridge, Polity Press

Granovetter, M. (1986) Economic Action and social structure: the problem of embeddedness. American Journal of Sociology, 91, 481-510.

Halpern, D. (2005) Social Capital Cambridge, Polity Press.

Johannisson, B. and Olaison, L. (2007) The Moment of Truth: Reconstructing entrepreneurship and social capital in the eye of the storm. Review of Social Economy, vol LXV, 1, 55-78.

Knack, S., and Keefer, P. (1997). Does social capital have an economic pay-off? A cross country investigation. Quarterly Journal of Economics. 112.4, 1251-1288.

Leonard, R. \& Onyx, J. (2003). Networking through loose and strong ties: An Australian qualitative study. Voluntas 14(2) 191-205.

Misztral, B. (1996) Trust in Modern Societies.: the Search for the Bases of Social Order Cambridge, Polity Press.

Mair, J., and Marti, I. (2006) social entrepreneurship research: a xource of explanation, prediction and delight. Journal of World Busines, 41, 36-44.

Onyx, J and Bullen, P. (2000) Measuring Social Capital in Five Communities. Journal of Applied Behavioral Science, 36, 1, 23-42. 
Onyx, J. and Leonard, R. (2000) Rural Renewal and Social Capital: the Case of Sweden and Australia. Working Paper 46, Centre for Australian Community Organisations and Management, University of Technology Sydney.

Portes, A. (1998) Social capital: Its origins and applications in modern sociology. Annual Review of Sociology, 24, 1-24.

Putnam, R. (1993) Making Democracy Work: Civic Traditions in Modern Italy. Princeton University Press.

Putnam, R. (2000) Bowling Alone: The Collapse and Revival of American Community. New York: Simon and Schuster.

Schuller, T. (2007) Reflections on the use of social capital. Review of Social Economy, vol LXV, $1,11-28$.

Staber, U. (2007) Contextualizing research on social capital in regional clusters. International Journal of Urban and Regional Research. 31.3, 505-521.

Terluin, I. (2003) Differences in economic development in rural regions of advanced countries: An overview and critical analysis of theories. Journal of Rural Studies. 19, 327-344.

Whiteley, P. (2000) Economic growth and social capital. Political Studies. 48, 443-466.

Woolcock, M. (1998) Social capital and economic development: Toward a theoretical synthesis and policy framework. Theory and Society ${ }_{2}$ vol.27, 151-208.

Woolcock, M. (2001) The place of Social Capital in understanding social and economic outcomes. Development Research Group, The World Bank, and Kennedy School of Government, Harvard University.

Woolcock, M. and Narayan, D (2000) Social Capital: Implications for Development Theory, Research and Policy. World Bank Research Observer, 15(2): 225-250. 
This is the peer reviewed version of the following article: Onyx Jennifer and Leonard Rosemary 2010, 'The conversion of social capital into community development: an intervention in Australia's outback', Blackwell, vol. 34, pp. 1-17. which has been published in final form at http://dx.doi.org/10.1111/j.1468-2427.2009.00897.x This article may be used for non-commercial purposes in accordance With Wiley Terms and Conditions for self-archiving' 